Ankara Sağllk Hizmetleri Dergisi,

Cilt 16, Sayı 1, 2017

\title{
Radyoterapi, Radyasyon Fiziği
}

\author{
Cengiz KURTMAN \\ ${ }^{1}$ Ankara Üniversitesi Tıp Fakültesi Radyasyon Onkolojisi Anabilim Dalı \\ Cebeci Eğitim ve Araştırma Hastanesi, Dikimevi, Ankara \\ e-mail:kurtman@medicine.ankara.edu.tr
}

\begin{abstract}
Özet
Radyasyon tıp alanında kullanılan önemli bir fizik parametredir. Sağlık alanında meslekleri gereği radyasyon ile çalışacak bireylerin radyasyon kavramını anlamaları kullandıkları malzeme ve cihazların önemini ve radyasyondan korunma için önemlidir. RA kelime veya hecesinden anlam kazanır. Radyasyon elektro manyetik enerji biçimidir. Özellikle iyonize edici radyasyon tıp alanında hastalıkların tanısı ve kanserin tedavisinde yaygın kullanılır. Partiküler radyasyonun etkileri farklıdır. Radyasyonun madde ve doku ile etkileşiminde ki basamaklar ve dozlar iyi bilinmelidir. Bu derlemede radyasyon fiziği konusunda temel hususlara vurgu yapılmıştır.
\end{abstract}

Anahtar Kelimeler: Radyoterapi, Radyasyon fiziği, İyonizasyon

\section{Summary}

Radiation is an important physics parameter used in medical field. It is important for individuals to work with radiation according to their occupations in the health field that the importance of radiation and the importance of the materials and devices they use and radiation protection. RA gets meaning from word or sentence. Radiation is the form of electromagnetic energy. Particularly ionizing radiation is widely used in the medical field for the diagnosis of diseases and for the treatment of cancer. The effects of particle radiation are different. The steps and doses in the interaction of radiation with matter and tissue should be well known. In this review, the basic issues of radiation physics are emphasized.

Key Words: Radiotherapy, Radiation physics, Ionization 
Radyoterapi, tıbbi görüntüleme, nükleer tıp konularında ki uygulamaları anlamak için radyasyonun tanımı ve radyasyonun temel fizik kuralları hakkında fikir sahibi olmak önemlidir.

Radyasyon 1şın olarak ta tanımlanabilir ve bir enerji türüdür. Elektro Manyetik Enerji (EME) olarak tanımlanır. Radyasyon kelimesi "RA" ile ilişkilidir ve tarihte 1şık, göz, tanrı ve bunun gibi anlamlar yüklenmiştir. Türk dilinde ve yabancı dillerde "RA veya RE" hecesinden türemiş çok kelime vardır (Radyasyon, Radyoterapi, Radyoaktif, Radyoloji, Radyo, Radikal, Radiks, Ray, Radar, Renk, Resim, Rahmet, Rahim..vbg).

EME geniş bir spektrumdadır; dalga boyu çok büyük, frekansı çok küçük ve enerjisi çok küçük olan uzun dalgadan sonra sırasıyla radyo, radyofrekans, mikrodalga, kızıl ötesi, görünür ışık, ultraviyole (mor ötesi), x-1şını, gama 1şını, foton gibi dalga boyu çok küçük frekansı çok büyük ve enerjisi çok yüksek özellikte 1şın türleri vardır (Khan ve ark., 2003). Temel olarak elektron koparmayan iyonize olmayan radyasyondan korkulmazken iyonize edici radyasyonun çok ciddi zararları oluşabilir ve radyasyondan korunma prensipleri çok önemlidir.

Mor ötesi, x-1şını, gama 1şını, foton gibi iyonize edici radyasyon tıp alanında; dermatoloji, nükleer tıp, tıbbi görüntüleme, radyoterapide kullanılır. İyonize edici radyasyon madde içinde ilerlerken atomların yörüngelerinden elektronlar kopararak ortamı iyonlaştırır ve bunun neticesinde canlı madde içinde istenilmeyen zararlar meydana gelir (Perez, 2013). Radyofrekans ve mikro dalga iyonize edici değildir ve tıp alanında fizik tedavide kullanılır. Diğer iyonize edici olmayan radyasyon tipleri radyo, televizyon, haberleşme, 1sitma vbg teknolojik alanlarda kullanılır.

İyonize edici radyasyon uzayda ve yerkabuğunda radyoaktif maddelerden oluşarak doğal olarak bulunur. Tıp alanında kullanılan iyonize edici radyasyon ise (Beyzadeoğlu, 2008);

1) Nükleer santrallerde maddelerin nötron bombardımanına tutularak radyoaktif hale getirilmeleri ile elde edilebilir. Nükleer tıpta kullanılan çok sayıda kısa yarı ömürlü radyoaktif madde vardır, radyoterapi alanında ise kobalt-60 radyoaktif maddesi eksternal radyoterapide ve iridyum-192 radyoaktif maddesi özellikle jinekolojik kanserlerde kavite/lümen içine brakiterapi şeklinde kullanılır (Tinkle ve ark., 2015). Radyoaktif maddeler çekirdekten dışarıya özellikle gama radyasyonu yayarlar, ayrıca elektron (beta), pozitron, nötron saçılması da söz konusu olabilir.

2) Gelişmiş elektrik ve elektronik teknolojileri ile yüksek gerilimle çalışan röntgen, skopi, tomografi, lineer hızlandırıcı, proton, betatron makinalarından elde edilir. Tıbbi görüntülemede ve radyoterapide kullanılır. Yüksek gerilimle çalışan cihazlarda cihazın Katot uçundan Anot ucuna doğru vakumlanmış ortamda elektronlar kinetik enerji ile hızlandırılarak anotta bulunan hedefe yönlendirilir. Anot da atom yapıların içine ve arasına gelen elektron yön değiştirerek kinetik enerjisini kaybeder ve elektronların kaybettikleri enerji ile uyumlu ve orantısal miktarda partiküler olmayan EME, foton veya x-1şını elde edilir. Şayet anot geri çekilirse elektronlar doğrudan dışarıya alınarak elektron ile radyoterapiye uygun partiküler radyasyon elde edilir.

EME dalga hareketi yapar, 1şık hızında hareket eder. İsminden de anlaşılacağı gibi elektrik ve manyetik alan kavramlarını içerir. Ortamda ilerlerken ve elektron yanından geçerken bu elektrik ve manyetik alanlar nedeni ile elektronu yörüngesinden iterek veya çekerek koparır. Atom yörüngesinde yer alan her elektronun çekirdeğe bağlanma enerjisi vardır. Gelen EME bu bağlanma enerjisinden büyük ise yörüngeden elektronları koparabilir.

Enerji (E): Plank Sabiti (h) x Frekans (f) veya

Enerji (E): h x 1/Dalga Boyu (K) veya

Enerji (E): Kütle (m) x Işıı Hızı (c) $)^{2}$ şeklinde formüle edilir. 
Frekans arttıkça enerji artar ve derinlere gitme özelliği artar. Dalga boyu arttıkça enerji azalır ve derinlere gitme özelliği azalır. Tıp alanında kullanılan cihazlarda amper (A), milisaniye (ms), voltaj (V) düğmeleri vardır.

Amper arttıkça ve milisaniye büyüdükçe cihazdan çıkan radyasyon sayısı (miktarı) artar, radyasyonun enerjisi ve delici özelliği değişmez.

Voltaj arttıkça cihazdan çıkan radyasyonun frekansı artar, enerjisi artar, delme özelliği artar. Voltaj arttıkça nispeten cihazdan çıkan radyasyon sayısı da artar. Ancak Voltaj arttırmanın esas amacı delici radyasyon elde etmek içindir.

EME madde veya ortamda ışı hızı ile ilerlerken;

1) Ortam ile etkileşmez, radyasyon geçip gider. Şöyle ki; Atomda çekirdek hacmi tenis topu boyutunda ve elektron toplu iğne boyutunda kabul edilirse çekirdek ile elektron arasında ki mesafe 10-20 kilometredir. Yani; aslında madde içinde büyük bir boşluk vardır ve bu boşluktan iyonize ve iyonize olmayan EME rahatlıkla geçebilir.

2) Ortam ile hafif uyarma etkisi olur, ancak elektron koparmaz. Isı oluşabilir.

3) Foto elektrik olay olur; bu olayda gelen EME atomun yörüngesindeki elektrona tüm enerjisini aktarır ve oradaki elektron koparak hareket eder, elektrona hız ve kinetik enerji vermiş olur. Gelen EME yok olur. Foto elektrik olay tıbbi görüntülemede belirgindir.

\section{Enerji Kinetik: Kütle (m) x Hız (v) ${ }^{2}$}

4) Compton etkisi olur; bu olayda gelen EME atomun yörüngesindeki elektrona değişik açılardan yaklaşarak elektronu yörüngeden koparır bir kısım enerjisini kopan elektrona aktarır ve elektrona hız ve hareket verir. Gelen EME yok olmaz, sadece enerjisinin bir kısmını elektronu yörüngeden koparmak için harcar ve diğer bir kısmını elektrona hız ve hareket olarak aktarır, kalan EME ışık hızında frekansı azalmış ve dalga boyu artmış vaziyette yani enerjisi artmış halde saçılarak ve yön değiştirerek yoluna devam eder. Compton etkisi radyoterapide ve komputarize tomografide belirgindir (Glover, 1982).

5) Çift teşekkülü; en az $1.02 \mathrm{MeV}$ EME 1şık hızında atomun çekirdek alanına yaklaştığında yok olur ve negatif yüklü elektron ve pozitif yüklü elektron (pozitron) çifti meydana gelir. $1.02 \mathrm{MeV}$ enejjiden daha fazlası varsa elektron ve pozitron üzerine hız ve hareket olarak aktarılır. Çok kısa süre sonrasında pozitron ortamda bulunan başka bir elektron ile etkileşime girerek pozitron ve etkileşime girdiği elektron yok olur ve en az $1.02 \mathrm{MeV}$ ve daha üstü enerjide EME o bölgeden yayılır, bu son yok olma durumuna "anihilasyon" (annihilation) denir. Çift teşekkülü nükleer tıp pozitron emisyon tomografide (PET) kullanılır (Lu ve ark., 2016).

6) Dezentegrasyon; Çekirdek yarılması ve çekirdek yırtılması olayıdır. Burada olayı başlatan EME değildir. Burada elektron veya daha büyük partiküller yüksek enerjilerle ve yüksek hızlarla çekirdek içine girip çekirdek içi düzeni bozarak yarılma yırtılma etkisi yapar ve ortama nötron, proton, elektron, EME (gama 1şını) tarzı enerjiler çıkar. Çok yüksek kinetik enerji ve isı oluşur. Nükleer enerji ve nükleer kazalarda gündeme gelen çok ciddi bir durumdur.

Tıp alanında bir işin ve işlemin gerçekleşebilmesi için gelen radyasyonun elektronları koparabilmesi gereklidir. İş elektronu koparmaktır. Burada işçi elektrondur. Elektron kopmaz ise iş gerçekleşmez, radyografi çekilmemiş olur, kanserli doku öldürülmemiş olur.

İyonize edici radyasyon partikül olmayan ve partikül olan radyasyon şeklinde iki temel guruptadır; 
1) Partikül olmayan radyasyonlar; $x-1 s ̧ ı 1$, foton, gama ışınıdır ve 1şık hızı ile hareket ederler, yüksek frekanslı olduklarında madde ve doku içinde çok derinlere giderler.

2) Partiküler radyasyonlar; elektron (beta), pozitron, alfa, proton, nötron, pi-mezon, ağır iyonlardır ve bilinen kinetik hız ile yani 1şık hızından daha düşük hızlarda hareket ederler (Tommasino ve ark., 2015). Partiküllerin kütleleri ve yükleri vardır, sadece nötron yüksüzdür. Kütle ve yükleri nedeniyle bir ortamda ilerlerken ortam elektronları ve atom çekirdek alanı ile etkileşme olasılıkları çok yüksektir. Bu nedenle çok fazla iyonlaşma yaparlar, ortama enerji aktarırlar, madde ve doku içinde çok derinlere gidemez ve canlı dokuda ciddi zararlara neden olurlar.

Yukarda bahsedildiği gibi; enerji aktarımı söz konusu ise elektron kopması şarttır. Elektron kopmamış ise enerji aktarımı ve radyasyon emilimi yoktur, iş yoktur.

Lineer Enerji Transferi (LET): Belli mesafede ortama aktarılan enerjidir. Ortama enerji aktarımı ancak elektron koparılabilmesi ile mümkündür. Belli mesafe en fazla enerji aktarımını yani elektron koparmayı kinetik hızla hareket eden büyük kütleli ve yüklü partiküller daha fazla yaparlar ve LET değerleri yüksektir. Partikül olmayan ve ışık hızı ile hareket eden foto ve gama 1şınlarının LET değeri düşüktür. Fotonun enerjisi düştükçe ortam ile etkileşimde foto elektrik olayın etki oranı artar ve elektron koparma artar, yani enerji aktarımı artmış olur. Düşük enerjili x-ışınlarının LET değeri daha fazladır.

Emilen Radyasyon Dozu (Radiation Absorbed Dose RAD): Birimi cGy dir. Maddenin 1 gr kütlesi tarafından emilen dozdur, 1 gr dokuya 100 erg enerji aktarmaktır. Yani 1 gr dokuda 100 erg karşılığ kadar elektronun koparılma işlemi için enerji harcanması gerekir. Elektron kopmamış ise radyasyon emilimi gerçekleşmemiştir. RAD veya cGy daha çok Radyoterapide işınlama hesaplamalarında kullanılır. Kanserli veya normal dokuların aldığı doz miktarını tanımlar.

Röntgen (R): Standart şartlarda $1 \mathrm{~cm}^{3}$ havada 1 esu yük birimlik akım meydana gelmesini ve iyon çiftleri oluşmasını sağlayan miktardır. Akımın meydana gelebilmesi için hava moleküllerinden elektronların kopartılarak iyonlaşma sağlanmalıdır. Röntgen havada isabet eden, maruz kalınan, hava ortamında ölçülen doz miktarıdır. Daha çok tıbbi görüntüleme işlemlerinde kullanılır.

Rölatif Biyolojik Etki (RBE): Farklı radyasyon tiplerinin canlıda aynı etkiyi oluşturması için gerektirdiği dozu hesaplamada kullanılır. Standart olarak $250 \mathrm{keV} \mathrm{x-1şının} \mathrm{yaptığı} \mathrm{etkinin} \mathrm{aynısını} \mathrm{elde}$ etmek için başka radyasyon tipi ile kullanılması gereken dozun oranıdır. RBE değeri partiküler radyasyonda ve düşük enerjili fotonlarda artar, yüksek enerjili fotonlarda RBE değeri düşer.

Memelilerde Eşdeğer Radyasyon (Radiation Equivalent Man-Mammalian REM): Birimi Sievert'dir. Memeli canlılarda değişik radyasyon tiplerinin memeli doku üzerinde yaptığı etkiyi eşleştirmek birbirine çevirmek için kullanılır. Değişik radyasyon tiplerinin rölatif biyolojik etkileri (RBE) üzerinden hesaplamalar yapılır. Burada alınan cGy (RAD) cinsinden değişik radyasyonların REM değeri bulunmak istenir. Temel hesapla 1 gr dokuya aktarılan erg üzerinden yapılır. Ancak bu aktarımı yapan radyasyonun tipi çok önemlidir ve biyolojik sonuç değişik olabilecektir. Daha çok nükleer tıp alanında, radyasyon alanında çalışanların uzun süre radyasyona maruz kalmalarında ve nihayet nükleer kazalarda çok önemlidir. Kazalarda birey veya çevre çok farklı radyasyon tiplerinden değişik oranlarda ve değişik sürelerde radyasyon alacağından hesaplama çok zor ama çok önemlidir (Khaer ve ark., 2014). 


\section{Kaynaklar}

Khan F.M. The Physics of Radiation Therapy, 2003 Third Edition, LIPPINCOTT WILLIAMS \& WILKINS 530 Walnut Street Philadelphia, PA USA

Carlos A. Perez. Principles and Practice of Radiation Oncology, 2013 Sixth Edition, WOLTERS KLUWER/ LIPPINCOTT WILLIAMS \& WILKINS, PA USA

Beyzadeoğlu M. Temel Radyasyon Onkolojisi, 2008 1. Bask1, GATA, Ankara, Türkiye

Tinkle CL, Weinberg V, Chen LM et al. Inverse Planned High-Dose-Rate Brachytherapy for Locoregionally Advanced Cervical Cancer: 4-Year Outcomes. Int J Radiat Oncol Biol Phys. 2015 Aug 1; 92 (5): 1093-100

Glover GH. Compton scatter effects in CT reconstructions. Med Phys. 1982 Nov-Dec; 9 (6):860-7.

$\mathrm{Lu} \mathrm{W}$, Chen W. Positron emission tomography/computerized tomography for tumor response assessment-a review of clinical practices and radiomics studies. Transl Cancer Res. 2016 Aug; 5 (4): 364-70.

Tommasino F, Durante M. Proton radiobiology. Cancers. 2015 Feb 12; 7(1): 353-81 -

Khare P, Nair P, Khare A, et al. The road to radiation protection: a rocky path. J Clin Diagn Res. 2014 Dec ;8 (12): 1-4. 
